\title{
O uso do índice de vegetação por diferença normalizada na análise multitemporal da cobertura vegetal no complexo industrial do município de Barcarena-Pará-Brasil
}

\author{
The use of the index of vegetation by normalized difference in the multitemporal analysis of \\ vegetation cover in the industrial complex of the municipality of Barcarena-Pará-Brazil \\ El uso del índice de vegetación por diferencia normalizada en el análisis multitemporal de \\ cobertura vegetal en el complejo industrial del municipio de Barcarena-Pará-Brasil
}

Recebido: 26/04/2021 | Revisado: 04/05/2021 | Aceito: 05/06/2021 | Publicado: 19/06/2021

Lilian Conceição Tavares

ORCID: https://orcid.org/0000-0003-0071-2932

Universidade Federal Rural da Amazônia, Brasil E-mail: lilianc.tavares@hotmail.com

Jamer Andrade da Costa

ORCID: https://orcid.org/0000-0001-7972-931X

Universidade Federal Rural da Amazônia, Brasil E-mail: jamer@terra.com.br

Ana Regina da Rocha Araújo

ORCID: https://orcid.org/0000-0002-6037-6582

Universidade Federal Rural da Amazônia, Brasil

E-mail: aregra55@gmail.com

Felipe Hermógenes Moraes Garcia

ORCID: https://orcid.org/0000-0001-7118-9830

Universidade Federal Rural da Amazônia, Brasil E-mail: felipegarcia25@hotmail.com

Francimary da Silva Carneiro

ORCID: https://orcid.org/0000-0002-1693-8779 Secretaria de Estado de Meio Ambiente e Sustentabilidade, Brasil

E-mail: francimarycarneiro@gmail.com

Ana Paula Magno do Amaral

ORCID: https://orcid.org/0000-0002-1749-791X Secretaria de Estado de Meio Ambiente e Sustentabilidade, Brasil E-mail: magno_ana@yahoo.com.br

Elayne Oliveira Braga

ORCID: https://orcid.org/0000-0001-9033-5602

Universidade Federal Rural da Amazônia, Brasil E-mail: elaynnebraga@hotmail.com

Thales de Souza Garcia

ORCID: https://orcid.org/0000-0001-6046-7743 Secretaria de Estado de Meio Ambiente e Sustentabilidade, Brasil E-mail: thalesg25@gmail.com

\begin{abstract}
Resumo
O complexo industrial de Barcarena-PA foi criado, por meio de um acordo bilateral entre Brasil e Japão, em 1976, com isso o município apresenta um grande crescimento industrial no decorrer dos anos e consequentemente uma grande quantidade de área desflorestadas. O objetivo deste trabalho foi analisar as imagens multitemporais da cobertura vegetal do Complexo Industrial no município de Barcarena- PA, entre os anos de 2006 a 2016. A metodologia consiste no uso das geotecnologias a fim de fazer a classificação do fatiamento das imagens multitemporais com o uso do NDVI em virtude das suscetíveis mudanças ocupacionais ocorridas na região do Complexo Industrial. Os resultados apontaram mudanças significativas ao longo dos anos, devido instalações de empresas, e o grande crescimento populacional que por não ter moradia nas cidades, passam a invadir áreas florestadas ao redor da cidade.
\end{abstract}

Palavras-chave: Municípios industrializados; Imagens multitemporais; NDVI.

\footnotetext{
Abstract

The industrial complex of Barcarena-PA was created, by means of a bilateral agreement between Brazil and Japan, in 1976, with that the municipality presents a great industrial growth over the years and consequently a large amount of deforested area. The objective of this work was to analyze the multitemporal images of the vegetal cover of the Industrial Complex in the municipality of Barcarena-PA, between the years 2006 to 2016. The methodology consists
} 
in the use of geotechnologies in order to classify the slicing of the multitemporal images with the use of NDVI due to the susceptible occupational changes that occurred in the region of the Industrial Complex. The results showed significant changes over the years, due to the installation of companies, and the great population growth that, due to not having housing in the cities, started to invade forested areas around the city.

Keywords: Industrialized municipalities; Multitemporal images; NDVI.

\section{Resumen}

El complejo industrial de Barcarena-PA fue creado, mediante un convenio bilateral entre Brasil y Japón, en 1976, con lo que el municipio presenta un gran crecimiento industrial a lo largo de los años y consecuentemente una gran cantidad de área deforestada. El objetivo de este trabajo fue analizar las imágenes multitemporales de la cubierta vegetal del Complejo Industrial del municipio de Barcarena-PA, entre los años 2006 a 2016. La metodología consiste en el uso de geotecnologías para clasificar el corte de la Imágenes multitemporales con el uso de NDVI debido a los susceptibles cambios ocupacionales que ocurrieron en la región del Complejo Industrial. Los resultados mostraron cambios significativos a lo largo de los años, debido a la instalación de empresas, y al gran crecimiento poblacional que, al no tener viviendas en las ciudades, comenzó a invadir las áreas boscosas alrededor de la ciudad.

Palabras clave: Municipios industrializados; Imágenes multitemporales; NDVI.

\section{Introdução}

A vulnerabilidade e os riscos gerados pelas tecnologias criadas para promover a evolução dos meios de produção e o bem estar social desencadeiam uma série de problemas, que afetam diretamente a cobertura vegetal e a qualidade de vida da população que está no entorno de empreendimentos industriais (Ribeiro et al. 2020, Santos et al. 2020, Rosário et al. 2021 \& Souza et al. 2021). Desta forma, é de total importância o uso das geotecnologias para acompanhar e até evitar futuras catástrofes no sistema biótico, abiótico e socioeconômico (Ribeiro et al. 2021 \& Coutinho et al. 2021).

Analisando o aspecto socioambiental, esses riscos (poluição do ar e da água, acidentes nas bacias de rejeitos, entre outros) estão sujeito a qualquer empreendimento da área mineral gerando graves consequências, tais como destruição de moradias de estruturas urbanas e rurais, isolamento de comunidades, impacto em plantações nas áreas rurais (estradas, pontes, entre outros), restrições à pesca, danos à saúde, mortandade da flora e fauna, poluição dos rios, entre outros (Ferreira, 2011).

O Complexo Industrial no Município de Barcarena-PA que abriga indústrias de produção e beneficiamentos minerais e portos de exportação, também esta sujeito a esses ricos. Barcarena sofreu intensas modificações a partir de 1985, segundo dados do IDESP (2014), este complexo havia se transformado em um município eminentemente industrial, sediando importantes empresas (Albrás, Alunorte, Pará Pigmentos, Imerys Rio Capim Caulim). Em 2014, tinha um PIB per capita de R\$ 34455.26. Na comparação com os demais municípios do estado, sua posição era de $4^{\circ}$ de $144^{\circ}$. Em 2015 , tinha $71 \%$ do seu orçamento proveniente de fontes externas e em comparação às outras cidades do estado, estava na posição $75^{\circ}$ de $144^{\circ}$.

Para a pesquisa ambiental, as geotecnologias destacam-se, segundo Oliveira \& Saito (2003), como instrumento de apoio, pois propicia a obtenção de informações de interesse a partir da integração geoespacial dos dados e modelagem de suas interrelações. Xavier da Silva (2007) e Zaidan (2004) enfatizam que o geoprocessamento é muito importante, porque se destina a tratar os problemas ambientais levando em conta a localização e quantificando as relações espaciais dos fenômenos analisados, visando contribuir para análise e acompanhamento da evolução passada e futura.

As geotecnologias podem ser definidas como o conjunto de tecnologias criadas para coleta de dados e geração de informações especializadas. Estando estas contempladas pelas técnicas de Sensoriamento Remoto (Processamento Digital de Imagens-PDI), Geoprocessamento (Sistemas de Informação Geográfica-SIG), Cartografia digital, Geodésia e outros (Hosokawa, 2014). Através das geotecnologias pode-se mapear e monitor a cobertura vegetal utilizando o Índice de Vegetação por Diferença Normalizada (NDVI), que quando avaliado de forma sazonal e em longo prazo é um importante indicador de quantificação da vegetação e redução da biomassa, gerando índices que servem de base para a classificação da vegetação. (Giongo, 2008).

O NDVI utilizado na pesquisa é uma técnica de PDI muito utilizada para estudos da vegetal (de Boratto \& Gomide, 
2013), que utiliza as diferenças entre as bandas da região do espectro eletromagnético do vermelho comparado com banda referente radiação infravermelho próximo, e se destaca pela sua utilidade em estudos sobre cobertura vegetal verde, podendo detectar áreas de perda e ganho de vegetação, estimativas de biomassa e índice de área foliar (ISAEV et al., 2002), além de minimizarem os efeitos de iluminação da cena, declividade da superfície e geometria de aquisição, que influenciam os valores de reflectância da vegetação (Ponzoni et al., 2012).

$\mathrm{O}$ índice de vegetação em Barcarena esta relacionando com as alterações na cobertura vegetal em função do crescimento urbano que tende a retirar boa parte da cobertura vegetal substituindo por áreas de construções, principalmente a partir de 1984, com a instalação da Albrás indústria mais importante do município, assim o crescimento urbano do município, modificou sua paisagem urbana, rural e social (Carmo \& Costa, 2016).

Lima \& Vieira (2009) afirmam que a fragmentação da cobertura vegetal em áreas urbana, e principalmente em vias públicas, é resultado direto do crescimento das cidades, que devido à necessidade de espaço acabam sendo substituídas ou restringidas a pequenas porções por vias para circulação de veículos e instalação de empresas.

Segundo Carmo e Costa (2016) no caso de Barcarena, assim como em outras cidades brasileiras, os grandes projetos foram responsáveis pela construção de áreas estratégicas que abrigavam, e ainda abrigam uma infraestrutura que atendia às necessidades dos trabalhadores da empresa. Nesse sentido, a modernização foi à realização não somente de um desejo, mas também, de uma necessidade para atender os setores privados. Contudo o cenário local apresenta uma grande mudança no de correr entre os anos de 2006 até o ano de 2016.

Este trabalho foi gerado com o objetivo de analisar a cobertura vegetal através das imagens multitemporais do Complexo Industrial no Município de Barcarena- PA, entre os anos de 2006 a 2016, utilizando geotecnologias a fim de fazer a classificação do fatiamento do NDVI em virtude das suscetíveis mudanças ocupacionais ocorridas na região.

\section{Metodologia}

A área de estudo corresponde a um polígono de 10422,18 ha localizado no município deBarcarena-PA e margeia a área adjascente de Abaetetuba (Figura 1). Barcarena pertence à Mesorregião Metropolitana de Belém e fica situada na região de Integração do Tocantins, uma região do Bioma Amazônico possui uma área de 1.310,588 Km², uma população estimada de 118.537 habitantes e densidade demográfica de 76,21 habitantes por $\mathrm{Km}^{2}$ (IBGE, 2016), Barcarena sede está localizada entre as coordenadas geográficas $48^{\circ} 52^{\prime} 19.907^{\prime \prime} \mathrm{W} 1^{\circ} 8^{\prime} 53.381^{\prime \prime S}$ e 48²4'38.521"W 1² $42^{\prime} 34.735^{\prime \prime S}$ (IDESP, 2014). 
Figura 1 - Mapa de Localização da Área de Estudo.

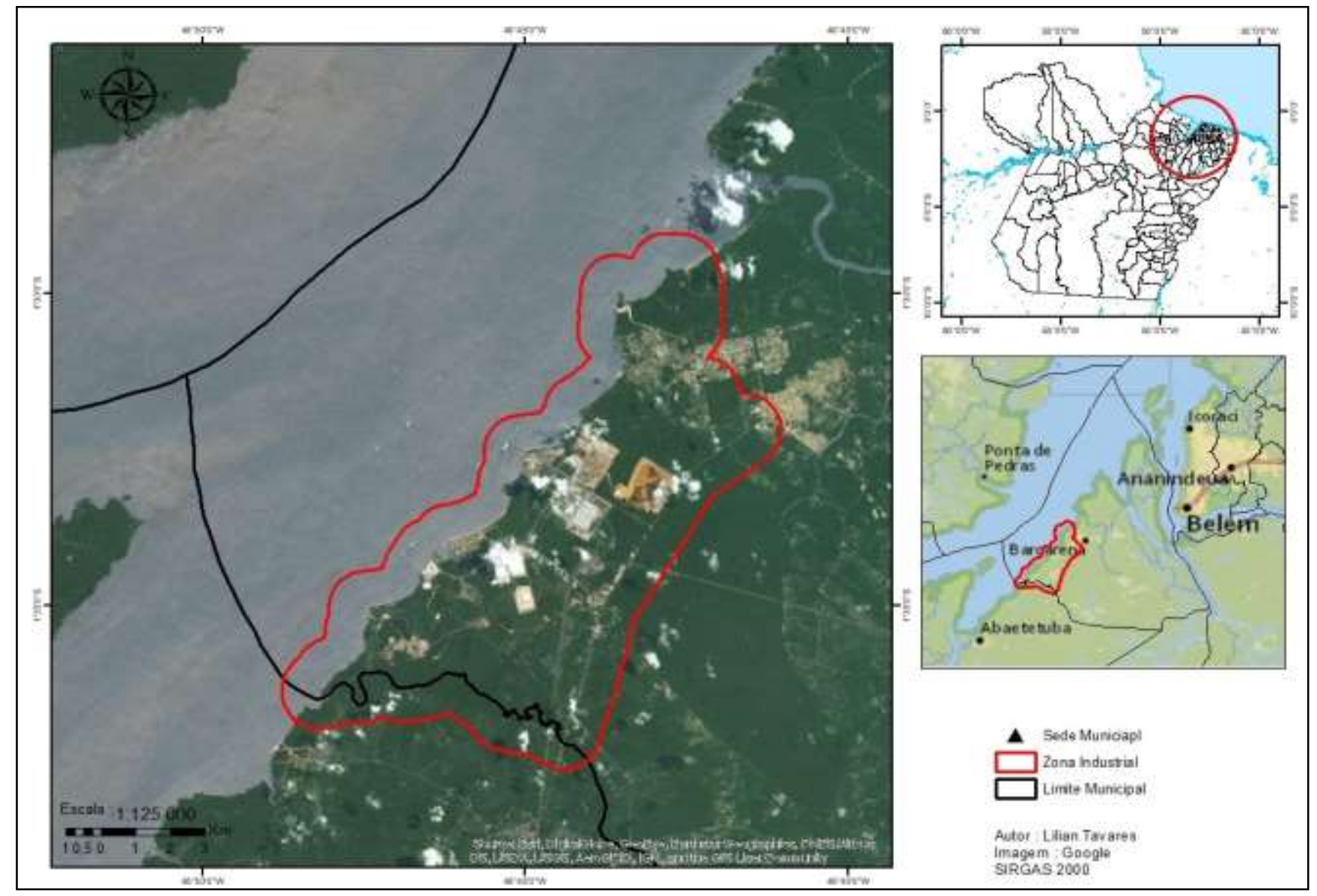

Fonte: Autores.

O polígono que delimita a área de estudo foi retirado do Plano Plurianual do Município de Barcarena (2014 a 2017) que está de acordo com os preceitos legais, nos artigos 165 da Constituição Federal e 204 da Constituição do Pará; Portaria nº 42, de 14 de abril de 1999, do Ministério do Planejamento Orçamento e Gestão - MPOG; Lei de Responsabilidade Fiscal LF no 101/2000; e o Inciso XXIX do Artigo 23 da Lei Orgânica do Município de Barcarena. O PPA é o principal instrumento de planejamento estratégico para a ação do Governo Municipal na implementação das políticas públicas, que serão materializadas em bens e serviços à nossa população.

A cobertura vegetal primitiva que pertence a Floresta Densa dos baixos platôs Pará/Maranhão foi quase totalmente substituída pela ação dos desmatamentos para o plantio de espécies agrícolas de subsistência, dando ensejo nas áreas em pousio à regeneração florestal com diferentes estágios de desenvolvimento da floresta secundária. As margens dos rios e igarapés predominam as Florestas Ciliares e de várzeas com influência de inundações, ocorrendo, também, o mangue e a siriúba, margeando os grandes rios e as ilhas do município (IDESP, 2014). O Município de Barcarena apresenta vegetação tipo hiléia, caracterizada por árvores de grande porte, por outro lado, se for levado em conta o processo de ocupação do solo amazônico, observa-se que:

Ao longo das margens dos rios e igarapés, preponderam as Florestas Ciliares e de várzeas nos trechos sob influência de inundações, ocorrendo, também, o mangue e a siriúba, margeando os grandes rios e as Ilhas do Município. (MPEG, 2002).

O Clima de Barcarena faz parte do clima quente equatorial úmido sendo, na classificação de Köppen, do tipo Am. A temperatura média anual é de $27^{\circ} \mathrm{C}$, com amplitude térmica mínima. Precipitações abundantes, acima de $2.500 \mathrm{~mm}$ ano, ocorrem mais nos seis primeiros meses e, menos intensamente, nos últimos seis meses do ano (IDESP, 2014). A vegetação 
representada na ilha é composta, basicamente, por matas primárias de terra firme, capoeiras, matas de várzea e campinas arenosa e praias de água doce (Amaral et al., 2002; Souza \& Lisboa, 2005; Teixeira et al., 2015).

A geologia do Município é pouco variável, construída, como em toda a microrregião, por sedimentos do Terciário (Formação Barreiras) e do Quaternário. Os primeiros estão presentes, sobretudo, na porção continental do Município, enquanto trechos Quaternários estão nas margens dos rios, constituindo a porção insularem do Município, onde predominam sobre a sedimentação da Formação Barreiras (Idesp, 2014).

O relevo reflete a geologia, estando presentes áreas de várzeas que são representadas por terrenos baixos e relativamente planos localizados próximos as margens dos rios. As áreas de várzeas altas são formadas por restingas, diques e cordões arenosos, com altimetria entre 3 e 12 metros, já as várzeas baixas são formadas por igapós e lagos, com altimetria entre 0 e 3 metros (Rima Albras/ Alunorte, 1984), terraços são representados por elevações que não sofrem influência da maré. Essas áreas apresentam altimetria variando entre 5 e 12 metros, estando associados a planície quaternária (Rima Albras/ Alunorte, 1984), o solo regional, apresenta as áreas de várzeas, terraços e tabuleiros, que constituem, regionalmente, um setor da unidade morfoestrutural, Planalto Rebaixado da Amazônia (Baixo Amazonas) (Idesp, 2014).

O município de Barcarena pertence à sub-região hidrográfica costa atlântica nordeste sob influencia da bacia hidrográfica dos rios Guamá-Moju. A Baía de Marajó é o principal acidente hidrográfico de Barcarena, em sua maior abertura para nordeste, compõe, com outras contribuições hídricas, o "Golfão Marajoara". Além desses dois elementos alguns furos separam a porção continental da porção insular do Município, entre os quais o furo do Arrozal, que separa a Ilha de Carnapijó e recebe o rio Barcarena e o rio Itaporanga, nasce ao sul do Município. O rio o furo e a baía Carnapijó cortam o Município de sudeste para noroeste. É importante pela navegabilidade como coletor da drenagem da região. Outro rio de expressão na área é o Moju, cuja foz limita com o município de Acará. Ao sudoeste, o rio Uruenga limitacom Abaetetuba e, a sudeste, o limite com Moju é feito através do Igarapé Cabresto (IDESP, 2014).

Na porção continental, os solos predominantes são o Latossolo Amarelo distrófico textura média, o Podzol Hidromórfico e Concrecionário Laterítico indiscriminado, distrófico, textura indiscriminada. Nas ilhas, estão presentes os solos hidromórficos indisciminados, eutróficos e distróficos, textura indiscriminada e HidromórficosGleisados, como o Gley Pouco Húmico e Aluvial eutróficos e distróficos, textura indiscriminada (IDESP, 2014).

Para os processos de tabulação dos dados, processamento digital de imagens, e integração em SIG, edição vetorial e análise espacial, etapas necessárias para o desenvolvimento deste trabalho, foi utilizada softwares, hardwares e demais equipamentos paraos procedimentos necessários para realização de trabalho. Os softweres utilizados para a realização dessa pesquisa foram: Arcgis 10.1, Envi 4.5 e QGis 2.18 Las Palmas de G.C.

A Confecção do Banco de Dados é a primeira fase do estudo, ele representa a fase de organização dos dados referentes à pesquisa realizada, a aquisição de imagens raster e vetores, as operações de processamento de imagens e geoprocessamento na integração de dados ambientais da cobertura do solo. 
Tabela 1 - Banco de dados geográficos.

\begin{tabular}{cccc}
\hline Arquivo & Formato & Escala & Fonte \\
\hline Limite Municipal & Vetorial & $1: 80.000$ & IBGE \\
Sede Municipal & Vetorial & $1: 80.000$ & IBGE \\
Hidrografia & Vetorial & $1: 80.000$ & IBGE \\
Rodovias & Vetorial & $1: 80.000$ & IBGE \\
Imagem Landsat5 & Raster & $1: 80.000$ & GLOVIS \\
Imagem Landsat8 & Raster & $1: 80.000$ & GLOVIS \\
Imagem CBERS & Raster & $1: 80.000$ & INPE \\
\hline
\end{tabular}

Fonte: Autores.

Primeiramente foi delimitado a área de estudo, o complexo industrial de Barcarena, o polígono JPEG retirado do Plano Plurianual de 2017 e transformador em formato vetor shapefile no software QGis 2.18.1 e posteriormente um buffer da área de $1 \mathrm{Km}$.

A aquisição de imagens se deu com bandas coletadas do site GLOVIS (https://glovis.usgs.gov) as imagens foram dos anos de 2006 a 2011 Landsat 5 e 2013 a 2016 Landsat 8, com exceção do ano de 2012 CBER o qual a imagem foi baixada do site do INPE. Todas com o mesmo objetivo de analisar o avanço do desflorestamento da cobertura vegetal durante esse período. As cenas utilizadas foram as das órbitas 224/61 (2006 até 2016) LandSat e162/2012 CBER4.

A imagem Landsat 7 do ano de 2012 (Figura 2.A) não pode ser utilizada, pois o satélite que margeou a mesma encontrava-se com falhas, assim não foi possível seu uso na classificação da cobertura vegetal. A Figura 2.B representa a imagem sem erros, assim utilizadas na pesquisa.

Nesse trabalho foram utilizadas 10 imagens de satélites, infelizmente grande formação de nuvens dificultou o resultado final do desenvolvimento da pesquisa.

Tabela 2 - Lista de Imagens utilizadas na pesquisa.

\begin{tabular}{ccc}
\hline Ano & Data De Aquisição & Identificação Da Imagem \\
\hline 2006 & 29_06_2006 & LT52240612006180CUB0011 \\
2007 & $31 \_05 \_2007$ & LT52240612007263CUB001 \\
2008 & $05 \_08 \_2008$ & T52240612008218CUB001 \\
2009 & $11 \_10 \_2009$ & LT52240612009284CUB001 \\
2010 & $26 \_07 \_2010$ & LT52240612010207CUB011 \\
2011 & 29_07_2011 & LT52240612011210CUB011 \\
2012 & 14_07_2015 & CBERS_4_PAN10M_20150714_162_102_L2 \\
2013 & 10_11_2013 & LC82240612013247LGN00 \\
2014 & 04_09_2014 & LC82240612014314LGN00 \\
2015 & 10_09_2015 & LC82240612015253LGN00 \\
2016 & 24_06_2016 & LC82240612016176LGN00 \\
\hline
\end{tabular}

Fonte: Autores. 
Figura 2 - A Imagem de Satélite Landsat 7/ 2012;B, Imagem de Satélite Landsat 8/ 2014

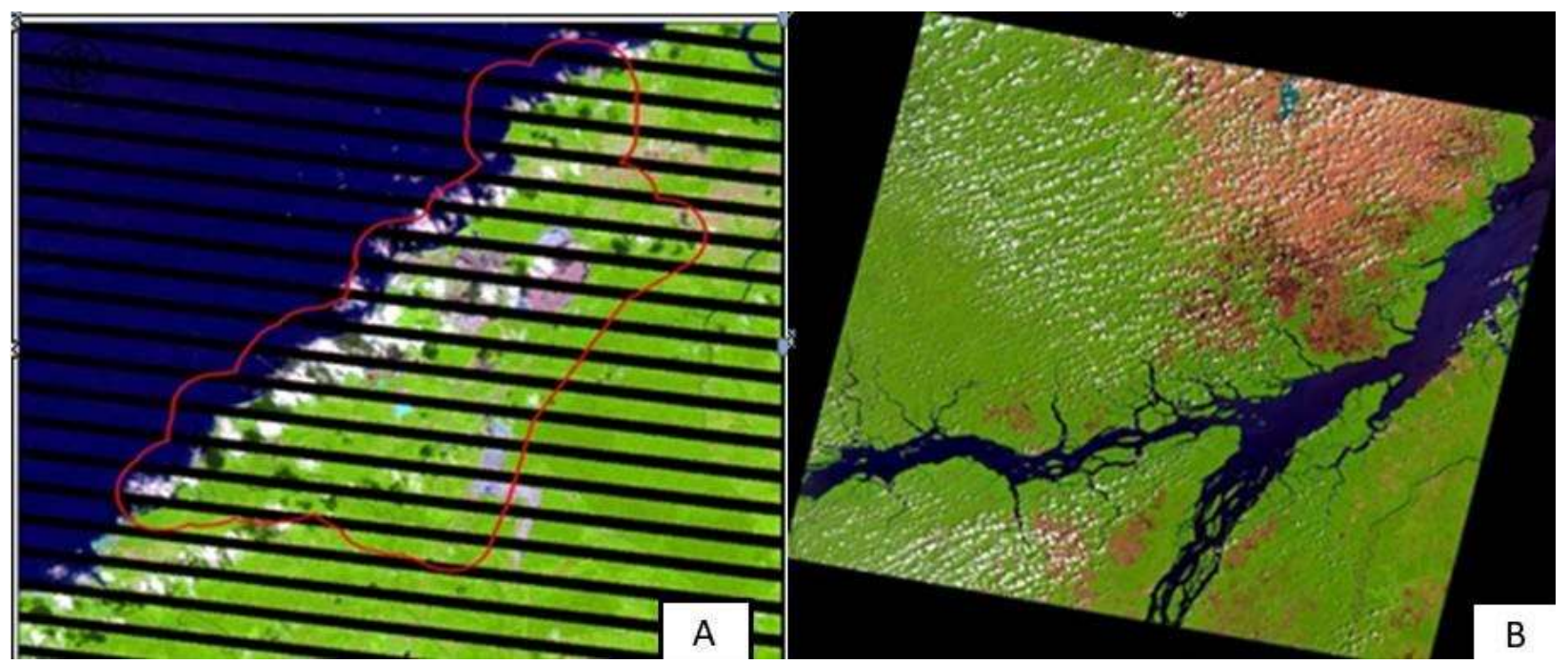

Fonte: Autores.

Para a composição de bandas foram utilizadas as senas b1, b2, b3, b4, b5, b7 da imagem do sensor TM/Landsat 5 e b2,b3,b4,b5,b6 e b7 do sensor TM/Landsat 8. Como as imagens vêm em escala de cinza, para o seu uso adequado, elas foram exportadas e tratadas, por meio do software ENVI 4.5 no qual realizou-se a confecção das composições coloridas em RGB (Red, Green, Blue) com diferentes combinações de bandas. Para compor o sensor CBER as bandas doforam b3,b4 e b5.

As composições coloridas possibilitaram uma escolha do melhor modo para fazer a análise interpretativa das manchas da região estudada, expondo assim diferentes cores, para diferentes comportamentos espectrais dos alvos na imagem. A composição utilizada para a obtenção das assinaturas foi a R5G4B3, para o sensor Landsat5 e R6G5B4 para Landsat 8 , a qual demonstraram ser mais adequadas para o estudo. E composição do sensor CBERS4 foi feito com suas 3 bandas 2R3G4B.

As imagens foram compostas nos software e ENVI, através da ferramenta Basic Tools- layer Stacking, com isso as imagens são compactadas em um único arquivo paraposteriormente serem georreferenciadas e recortadas (Figura 3).

$\mathrm{O}$ arquivo shapefile utilizado na delimitação da área de estudo, zona industrial de Barcarena - PA estavam em coordenadas geográficas com o Datum WGS 84 e transformado para o Datum SIRGAS 2000. As imagens foram convertidas em para a projeção Sirgas 2000. Os incrementos shapefiles gerados pelas imagens foram convertidos em sirgas 2000 UTM $22 \mathrm{~S}$.

Para segurar que a imagem já estava georreferenciada, imagens GLOVIS USG possuemalta precisão na correção de deslocamento, foram retirados 20 pontos aleatoriamente das principais áreas, com o intuito de tabular as coordenadas e assim validar o georreferenciamento.

Após a delimitação da área de estudo com o buffer de 1km, e a composição das bandas Landasta5, Landsat8 e Cbers, as imagens foram recortadas com base no arquivo vetor da áreada zona industrial localizada em Barcarena e Abaetetuba. Todas as imagens foram recortadas através do software ENVI 4.5, com o intuito de deixar apenas a área de interesse.

$\mathrm{O}$ índice de vegetação por diferença normatizada (ndvi) o índice é calculado pela equação abaixo, a qual tem como variáveis a reflectância dasbandas do vermelho (red) e do infra-vermelho próximo (nir): NDVI = (NIR-RED)/(NIR+RED). 
Tabela 3 - Bandas NDVI.

\section{Bandas}

Sensores

\begin{tabular}{lccc}
\hline & Landsat 5 & Landsat 8 & Cbers \\
Banda do Vermelho & 3 & 4 & 2 \\
Banda do Infravermelho Próximo & 4 & 5 & 3 \\
\hline
\end{tabular}

Fonte: Autores.

Para a obtenção dos dados, foi utilizado o Software ENVI 4.5 específico para Processamento Digital de Imagens (PDI), para procedimentos que necessitam de uma plataforma de Sistema de Informação Geográfica (SIG) foi utilizado o software ArcGis 10.1.

Foi necessário reclassificar a imagem para que novos atributos sejam dados a cada píxel que possuírem valores no intervalo estabelecido de NDVI, pois segundo Jensen (2009) o índice sofre influência de radiância de trajetória atmosférica, apresenta saturação em relação a altos valores de Índice de Área Foliar (IAF) e tem sensibilidade às mudanças do substrato do dossel, como o solo. Elmore et al. (2000) afirma que outra desvantagem do índice NDVI está no fato deste ser altamente influenciado pelo brilho e efeito espectral do solo, fato que prejudica as avaliações sobre a vegetação.

Após a aplicação da álgebra de mapas procede-se com a classificação temática dos resultados obtidos, por meio do método de segmentação dos valores a partir da função Density Slice do software ENVI 4.5 para ter um maior contraste entre a razão das bandas de modo a estabelecer os intervalos temáticos de cada índice.

A validação da classificação temática foi realizada software ENVI 4.5 por meio da interpretação da matriz de erros, que apresenta a tabulação cruzada entre os planos de informação referentes à fotointerpretação da composição em cor natural RGB, considerada como referência e pela classificação obtida a partir do índice NDVI.

Para tanto, realizou-se a captação de alguns pontos aleatórios na composição RGB retirados do softwere QGis 2.18.1. O erro global de classificação para cada classe temática é identificado pela matriz que, por sua vez, expõe como ocorreram os conflitos entre elas e também exibe os pixels classificados corretamente.

Segundo Meneses (2012) as técnicas de classificação digital de imagens, que automatizam o processo de extração de informações das mesmas, eliminam a subjetividade da interpretação humana e reduz o esforço de trabalho do analista gerando o resultado final da classificação, sendo uma imagem digital que constitui em um mapa de pixels classificados, representando em polígonos os padrões homogêneos de classes de alvos (mapa digital temático).

A resposta da classificação digital de imagens de satélites pode variar de acordo com a aquisição de imagens, a influência de nuvens, sombras e relevo influenciam bastante no resultado alcançado, assim como a resolução espacial, espectral e radiométrica do sensor. A maioria dos satélites artificiais de imageamento, denominados passivos, dependem de umafonte de iluminação secundária (solar) para captar e gerar imagens da superfície terrestre. Portanto, áreas com relevo acidentado terão maior ocorrência de sombra do lado oposto à incidência solar. Segundo Moreira (2001) como a incidência de luz solar é muito baixa emáreas com sombra, com isso pouca energia refletida chegará aos sensores do satélite, ou seja, as sombras provocadas pelo próprio relevo fornecerão dados inconsistentes em relação à assinatura espectral dos alvos captados.

A classificação foi feita pelo método de fatiamento (Density Slice), sendo um processo de extração de informações em imagens para reconhecer padrões e objetos homogêneos com o objetivo de mapear as áreas da superfície terrestre. Cada cor está associada a uma classe (solo, água e vegetação), baseando-se nas propriedades espectrais e espaciais destas imagens. Para 
a classificação da imagem precisa-se de colher amostras, isso quer dizer selecionar grupos de pixels que correspondem a uma determinada classe.

As classes utilizadas foram:

- Floresta DES:Segundo Salomão (2012) o estágio inicial de sucessão (capoeirinha) surge em áreas agrícolas ou em pastagens abandonadas ocorrendo até cinco anos, podendo, em alguns casos, durar até dez anos em função do grau de degradação do solo ou da escassez de fontes de propágulos. Nas capoeirinhas, geralmente há o predomínio de plantas herbáceas anuais ou bianuais, aparecendo também exemplares de árvores pioneiras de poucas espécies. A altura média das árvores, em geral, é de $6 \mathrm{~m}$ e o diâmetro médio a 1,30 m do solo (Diâmetro à Altura do Peito - DAP) é de, aproximadamente, $7 \mathrm{~cm}$. O estágio intermediário desucessão (capoeira) a vegetação geralmente alcança o estágio intermediário entre os dez e 20 anos de idade neste estágio, as árvores atingem altura média de $8 \mathrm{~m}$ e DAP de 9 cmcaracterizam como arbustivo-arbórea. E já o estágio avançado de sucessão (capoeirão) inicia- se geralmente depois dos 20 anos de regeneração natural da vegetação, nesse estágio de sucessão a altura média das árvores é superior a $10 \mathrm{~m}$ e o DAP médio é superior a $11 \mathrm{~cm}$.

Classificação:

- Não Floresta; áreas que não apresentam vegetação são áreas de solo exposto, áreas de construção, áreas industriais, áreas urbanas, entre outras.

- Massa d'água: representa rios, lagos e um infinito de tipo de água,

- $\quad$ Nuvem e Sombra: é um fator de perturbação significativo, pois estas classes não são totalmente uniformes. Por exemplo, na região de penumbra ocorre alta mistura entre a "sombra" e a cobertura do solo, com isso foram classificadas manualmente.

As imagens apresentaram grande quantidade de nuvens e sombras, tornando difícil a identificação de alguns delas pela classificação feita pelo NDVI, com isso muitas foram classificadas manualmente e inseridas nos gráficos e mapas.

Os mapas multitemporais da cobertura vegetal foram elaborados após a classificação das imagens, através dos software ENVI as imagens foram classificadas e exportadas para o software Arc Gis 10.0, onde os arquivos raster e vetorial passaram pelos ajustes finais e apresentados no Layout com grids, rosa-dos-ventos, escala e legenda.

Os gráficos foram gerados na planilha de Excel, as atributações foram classificadas e exportadas da tabela de atributos gerada no ArcGis.

\section{Resultados e Discussão}

As áreas identificadas localizadas dentro da área de estudo, zona Industrial, apresentam as principais empresas no Distrito de Barcarena (Figura 3 e Figura 4). 
Figura 3 - Imagem da Zona Industrial 2006

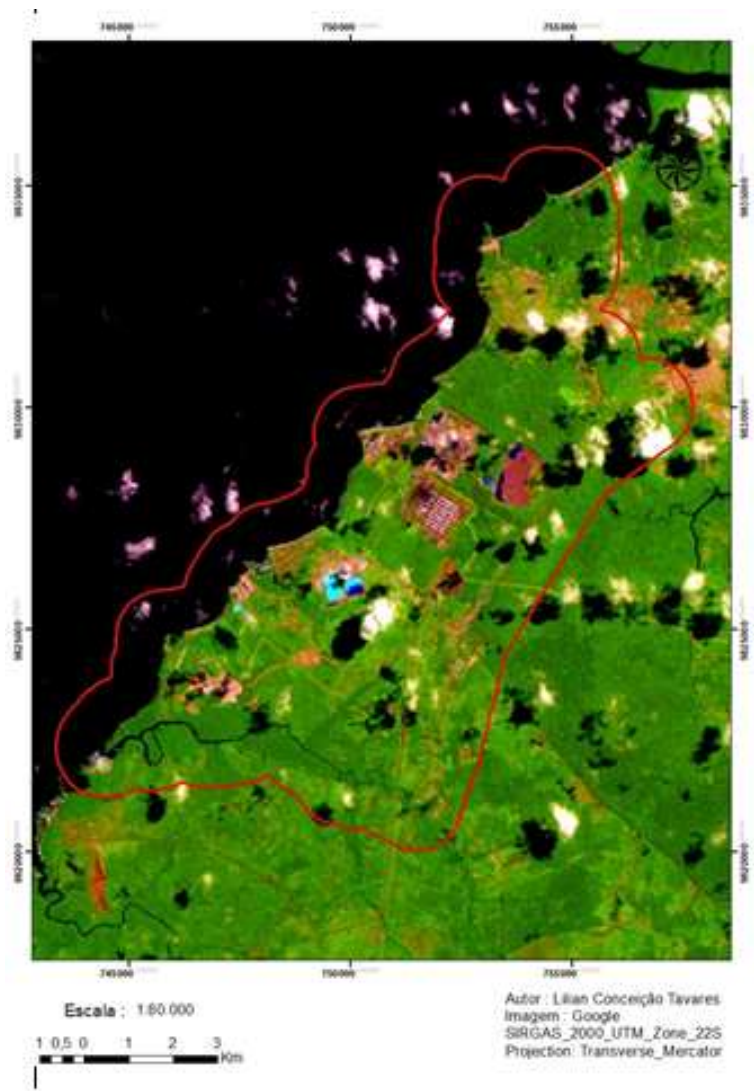

Figura 4 - Imagem da Zona Industrial 2012

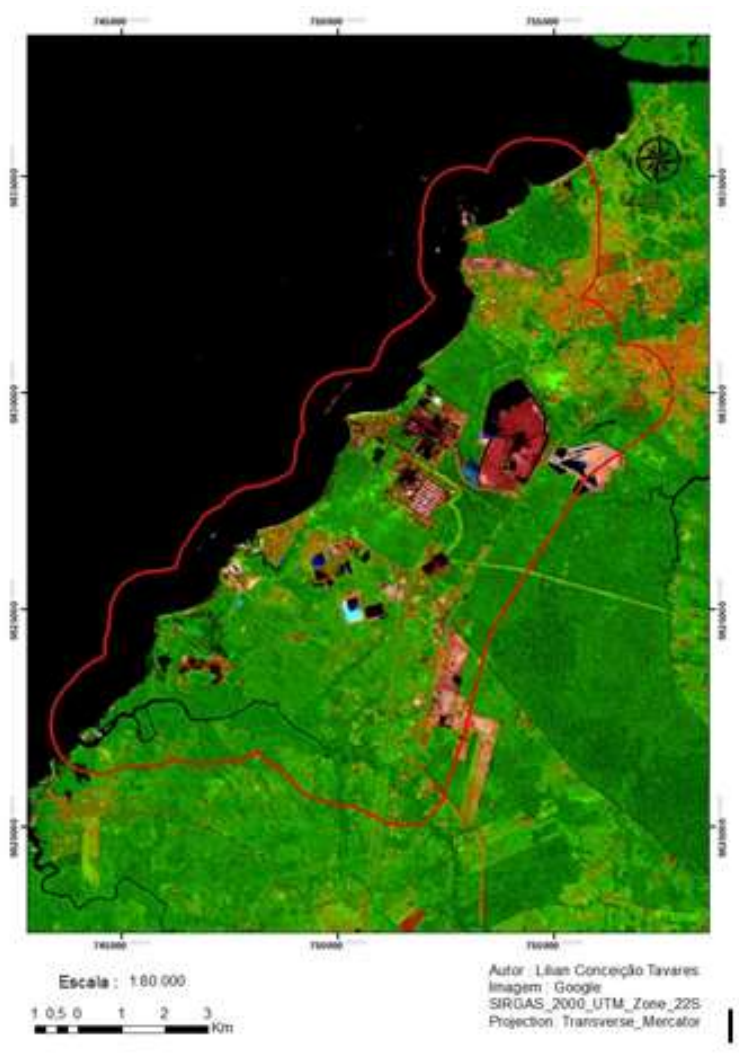

Fonte: Autores.

As imagens acima são do ano de 2006 e 2012, e mostram a diferença da cobertura vegetal no entre esses anos, as nuvens e sombras dificultaram um pouco a visualização da imagem de 2006, mas pode-se observar que a cobertura vegetal não modificou apenas com a presenças das empresas, mais sim pelo crescimento desordenado da população.

Os valores resultantes dos incrementos classificados foram gerados e convertidos em gráficos comparativos de cada ano trabalhado.

A classificação das imagens de 2006 até 2016 em uma área de 10422,18 ha referente à área de estudo que compreende a zona industrial de Barcarena-PA. Foi classificada em FlorestaDES (Floresta em Diferentes Estágios Sucessionais), Massa d'água, Não Floresta e Nuvem e Sombra. O ano de 2006 foi o primeiro das análises, a quantidade de nuvem e sombra dificultouum melhor acurácia dos resultados.

O ano de 2006 a área de floresta apresentava 4388, 74 ha e a Não Floresta 2981,57 ha (Gráfico 1) 
Gráfico 1 - Área desfragmentada 2006.

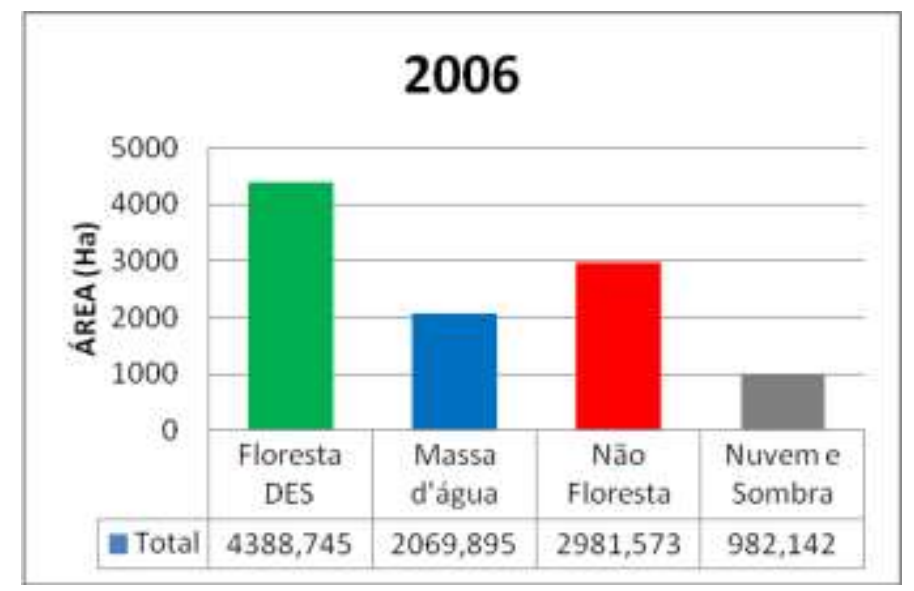

Fonte: Autores.

A imagem da área de estudo em 2006 apresentou grande quantidade de nuvens, e consequentemente as suas sombras gerando um área de 982,142 ha, contudo a área inicial da pesquisa de Floresta DES tem um valor extremamente considerável.

O Ano de 2006 foi marcado pela expansão do polo de industrialização, através das fábricas metal-mecânicas, dentre as quais se destacam a Alumínio Brasileiro S/A (Albras), essas linhas, em conjunto com as três existentes, elevaram a capacidade da planta de 2,4 para 4,4 milhões de toneladas/ano de alumina, consolidando a Alunorte como a maior produtora de alumina do mundo. Desde 2006, a 3 empresa investiu na construção de duas novas linhas produtivas, que elevarão a capacidade de 4,4 para 6,3 milhões de toneladas/ano de alumina (Nascimeto, 2010).

No ano 2007, o resultado da área desfragmentada, apresenta uma significativa mudança na área de Floresta DES que diminuiu 359.415ha e consequentemente a área de Não Floresta teve um crescimento de 983.674 ha, levando em consideração os valores de nuvem em sombra. A consequência desse valor resultou-se da instalação de grandes projetos que foram responsáveis pela construção de áreas estratégicas que abrigavam, e ainda abrigam, uma infraestrutura que atendia às necessidades dos trabalhadores da empresa.

Em 2008 (Gráfico 3) e 2009 (Gráfico 4) os índices calculados continuam apresentando mudanças, as áreas de Floresta DES de ainda estão diminuindo e consequentemente às áreas de Não Floresta aumentam. 
Gráfico 2 - Área desfragmentada 2007.

Gráfico 3 - Área desfragmentada 2008.

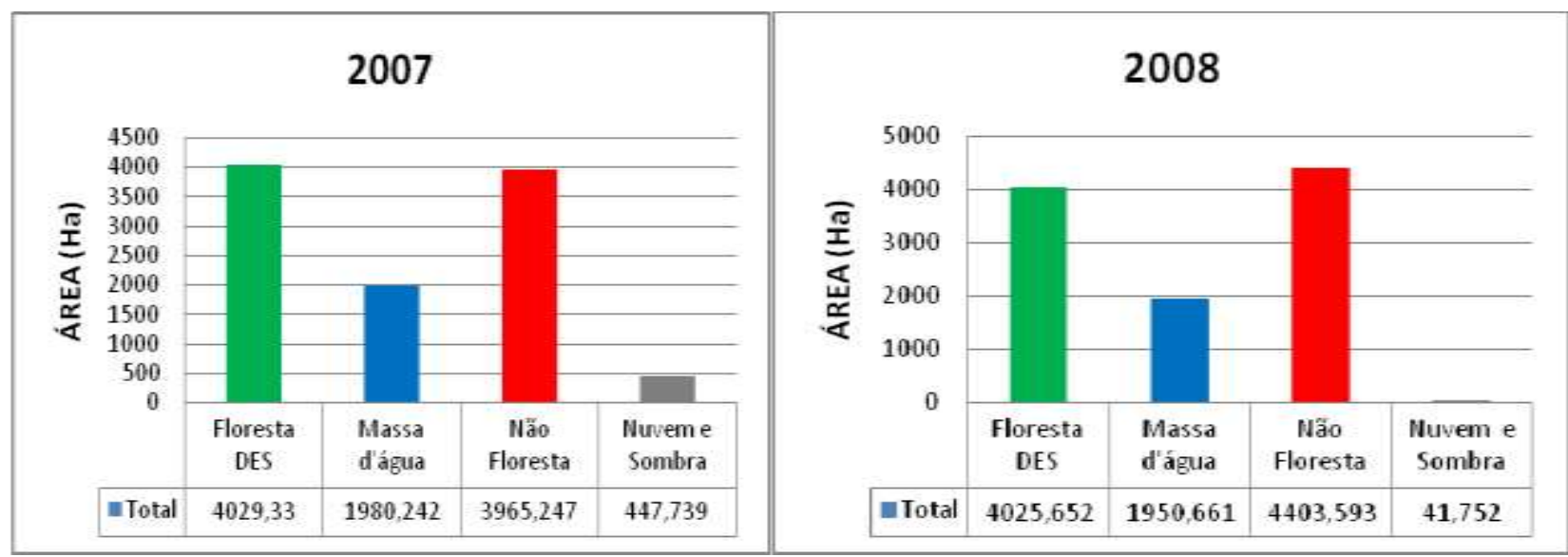

Fonte: Autores.

Segundo o Diário de Comércio e indústria - DCI (2010), no ano de 2008, a Vale inaugurou a terceira fase de expansão da Alunorte, que contempla duas linhas de produção para aumentar a capacidade atual de 4,45 milhões para 6,3 milhões de toneladas de alumina por ano. A capacidade de produção da Alunorte, a partir da expansão, supera a produção brasileira total de alumina em 2005, que foi de 5,1 milhões de toneladas. Com isso os anos de 2007 (Gráfico 2) a 2008 que apresentou apenas 3,68 ha a menos, em 2008 para 2009 a área de Floresta DES apresentou uma diminuição de 40,646 ha.

Gráfico 4 - Área desfragmentada 2009. G Gáfico 5 - Área desfragmentada 2010.

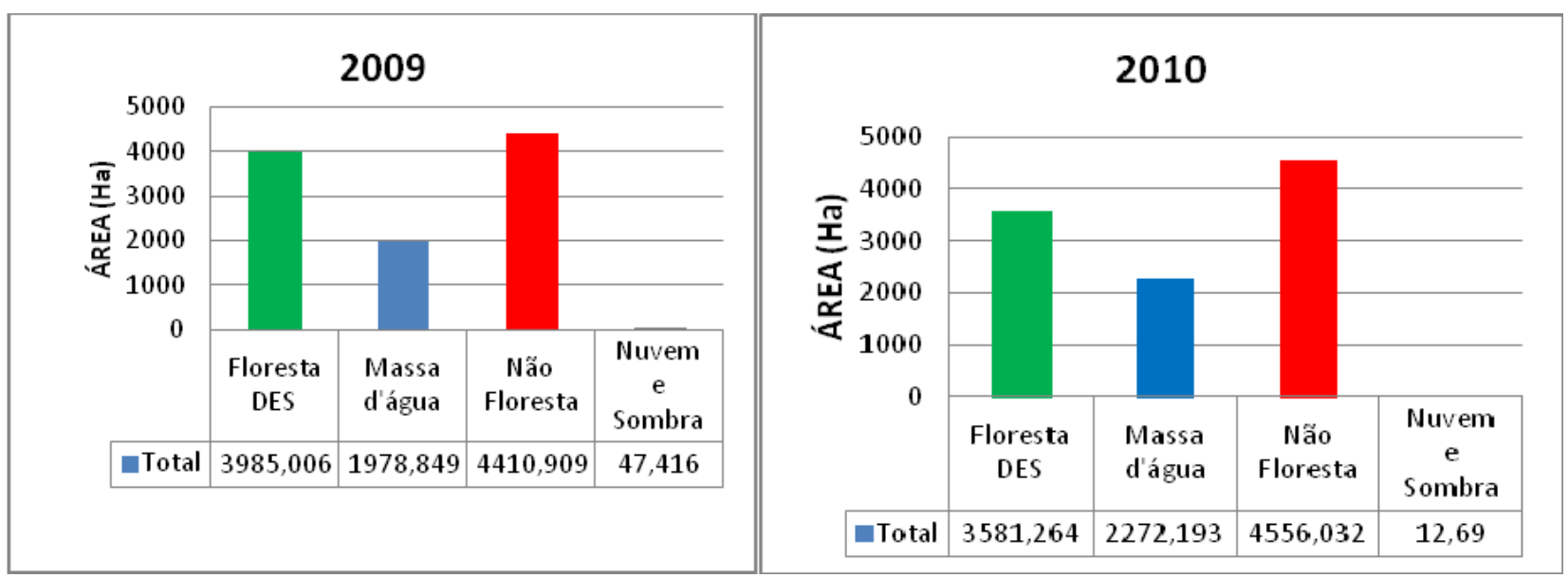

Autores.

No ano de 2010 (Gráfico 5) e 2011 (Gráfico 6) os índices calculados continuam apresentando mudanças, as áreas de Floresta DES continuam diminuindo e consequentemente as áreas de Não Floresta aumentam. 
Gráfico 6 - Área desfragmentada 2011.

Gráfico 7 - Área desfragmentada 2012.

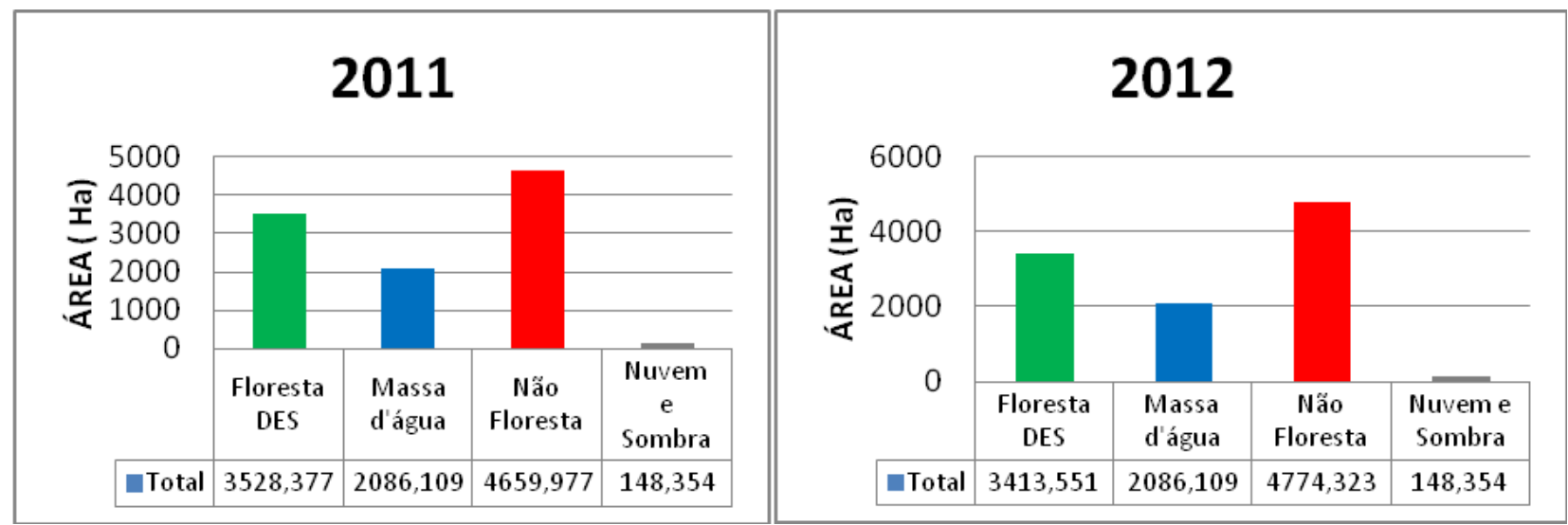

Fonte: Autores.

Apesar do ano de 2012 (Gráfico 7) ocorrer a consolidação do novo código floresta, as áreas de Floresta DES apresentaram crescimento apenas no ano de 2015, consequentemente ocorreu o decréscimo na área não Florestada.

Gráfico 8 - Área desfragmentada 2013.

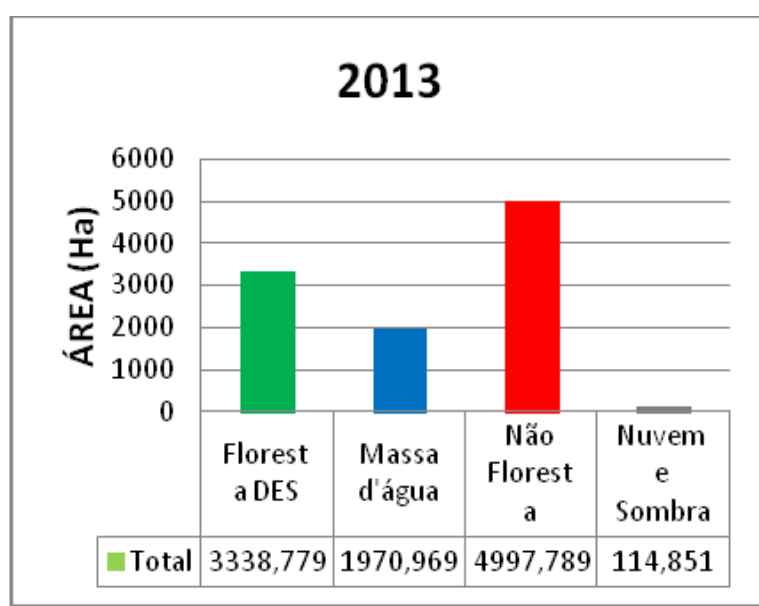

Gráfico 9 - Área desfragmentada 2014.

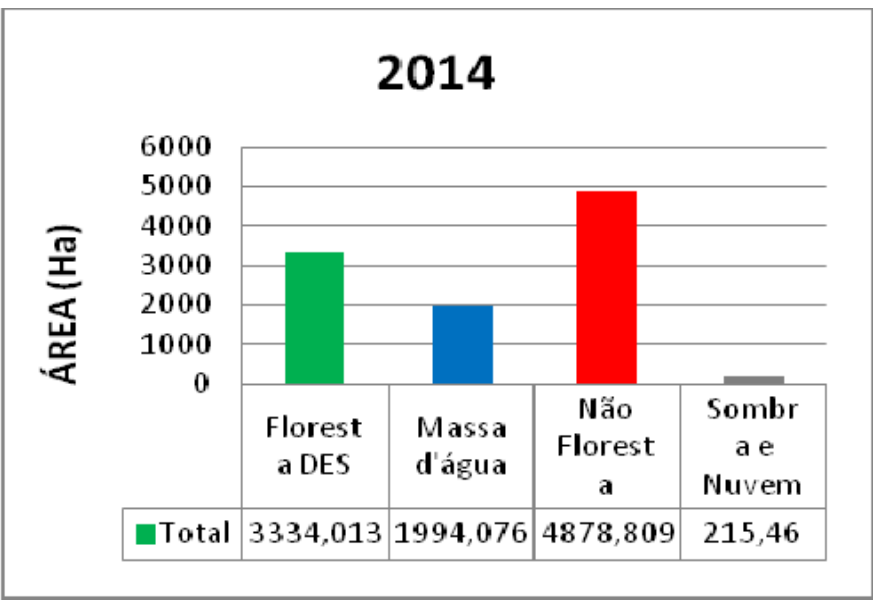

Fonte: Autores.

No ano de 2016 (Gráfico 11) foi ultimo ano da pesquisa, e o gráfico apresenta o resultado final da área de Floresta DES, Massa d'água e Não Floresta, a imagem LandSat 2016 apresentou um ótimo imagiamento, e ausencia de nuvens, assim pode-se afirmar que a no decorrer de 10 anos a área de Floresta DES que em 2006 possuía 4388,745 ha passou para uma área de 3837,915 ha. Assim houve diminuição na cobertura vegetal de 550. 083 ha acarretado sérias consequências ambientais e socioeconômicas. 
Gráfico 10 - Área desfragmentada 2015.

Gráfico 11 - Área desfragmentada 2016.

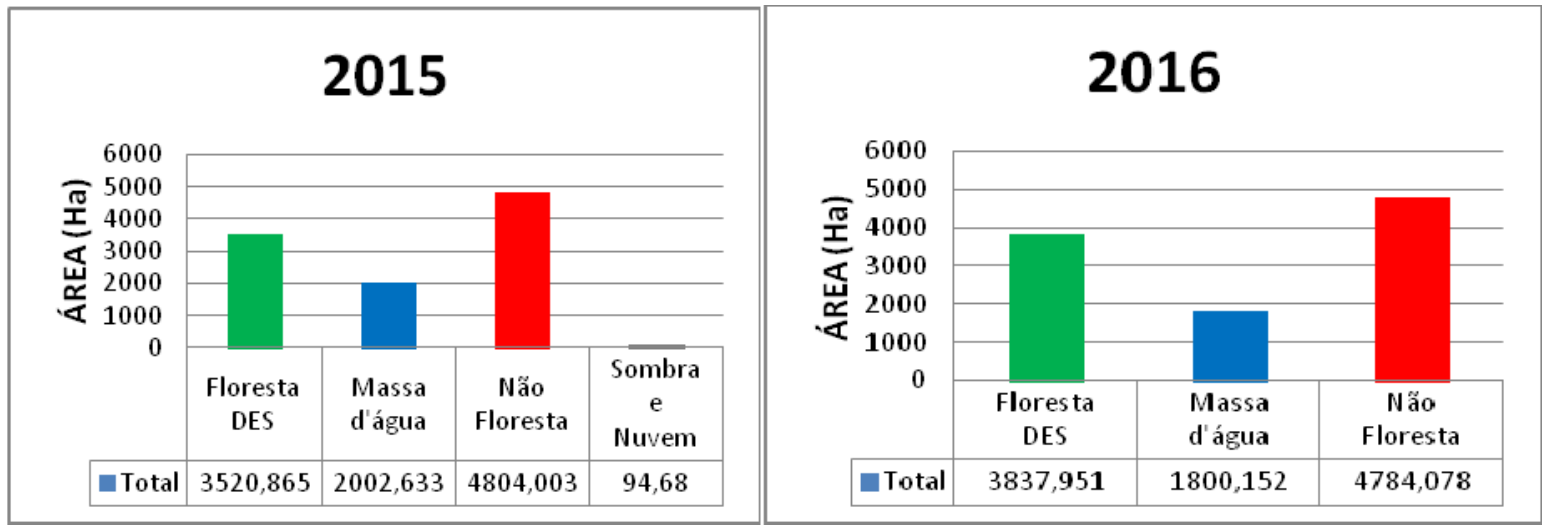

Fonte: Autores.

As imagens listadas abaixo mostram visivelmente e gradativamente a mudança nosenário de estudo, identificando as áreas que sofreram com a diminuição da cobertura vegetalDES e o avanço da área de Não Floresta.

Figura 5 - NDVI 2006.

Figura 6 - NDVI 2007.

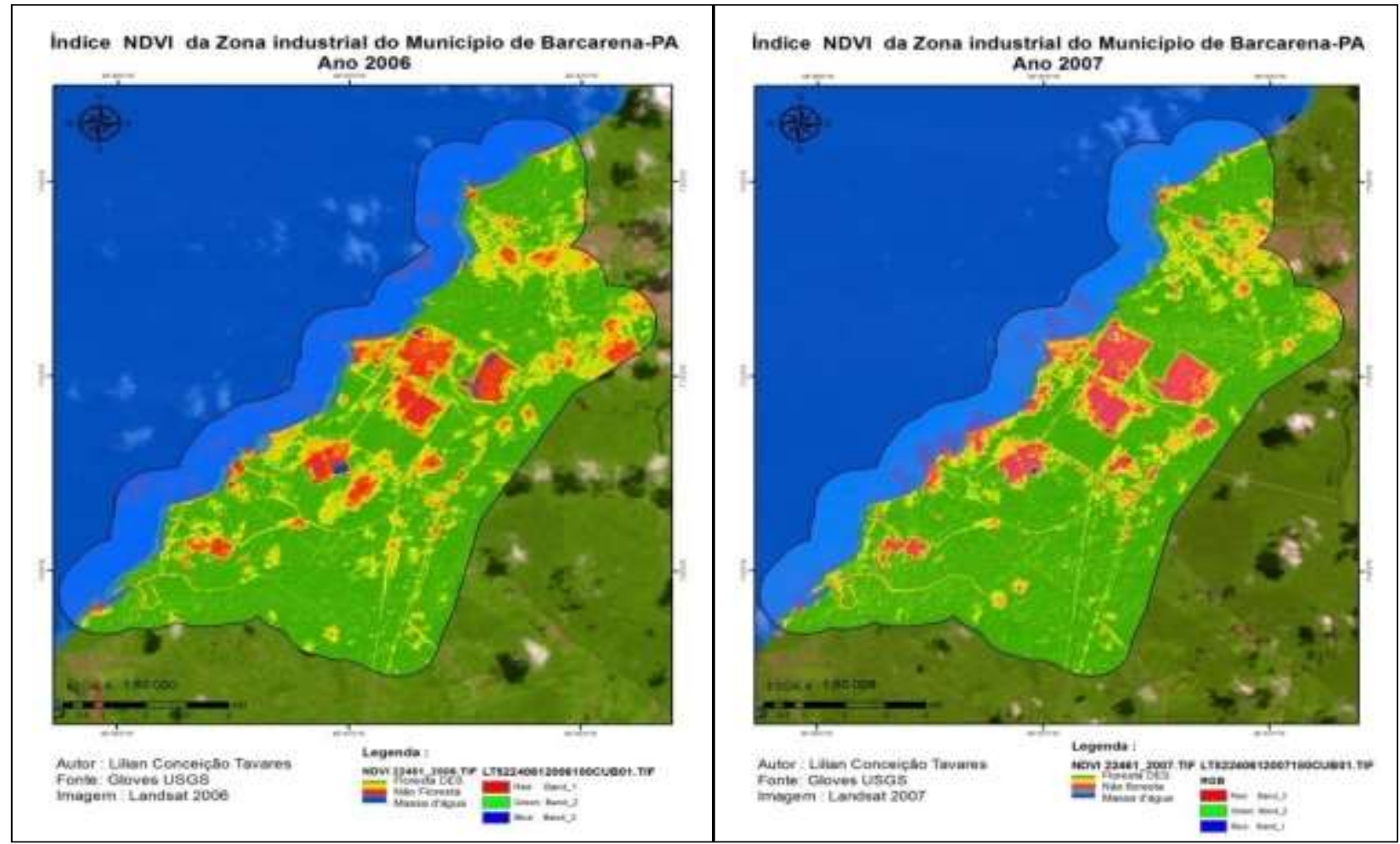

Fonte: Autores. 
Research, Society and Development, v. 10, n. 7, e23010715470, 2021

(CC BY 4.0) | ISSN 2525-3409 | DOI: http://dx.doi.org/10.33448/rsd-v10i7.15470

Figura 7 - NDVI 2008.

Indice NDVI da Zona industrial do Municipio de Barcarena-PA Ano 2008

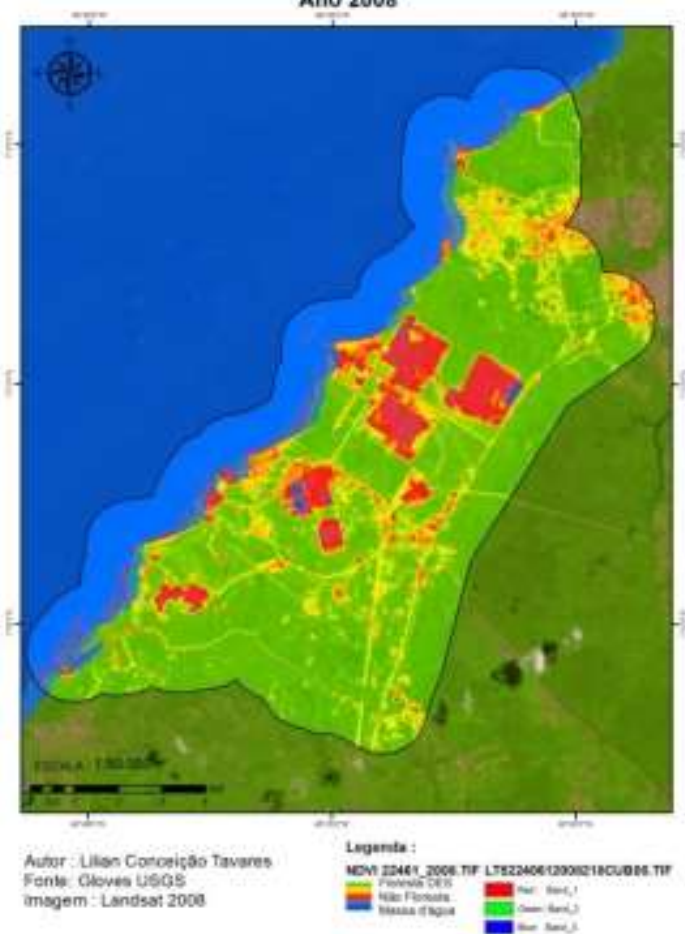

Figura 8 - NDVI 2009

Indice NDVI da Zona industrial do Municipio de Barcarena-PA Ano 2009

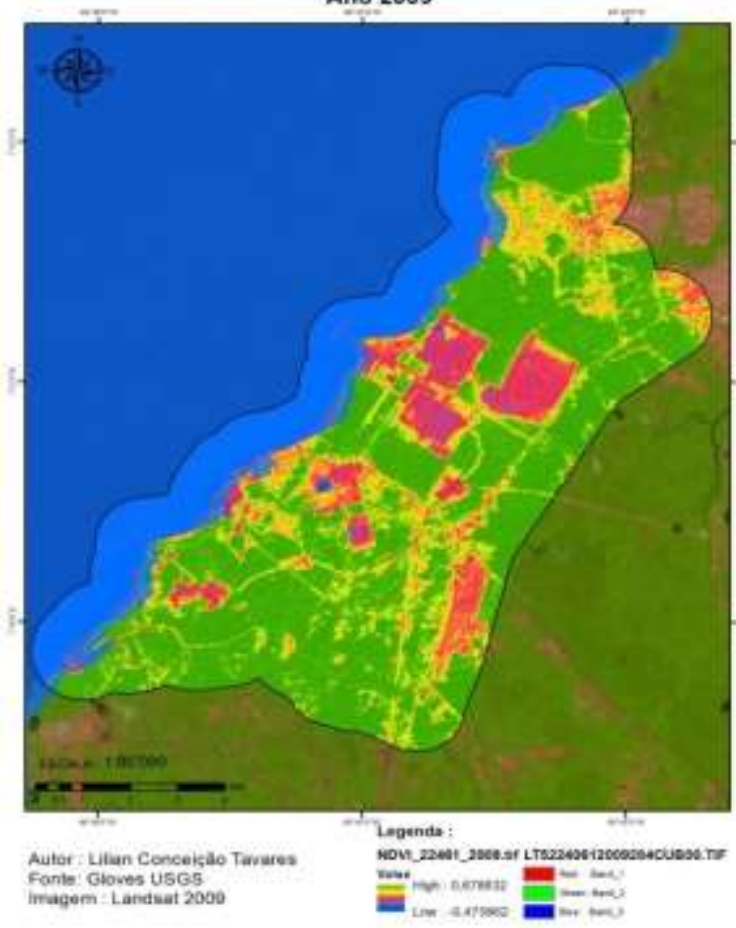

Fonte: Autores.

Figura 9 - NDVI 2010.

Figura 10 - NDVI 2011

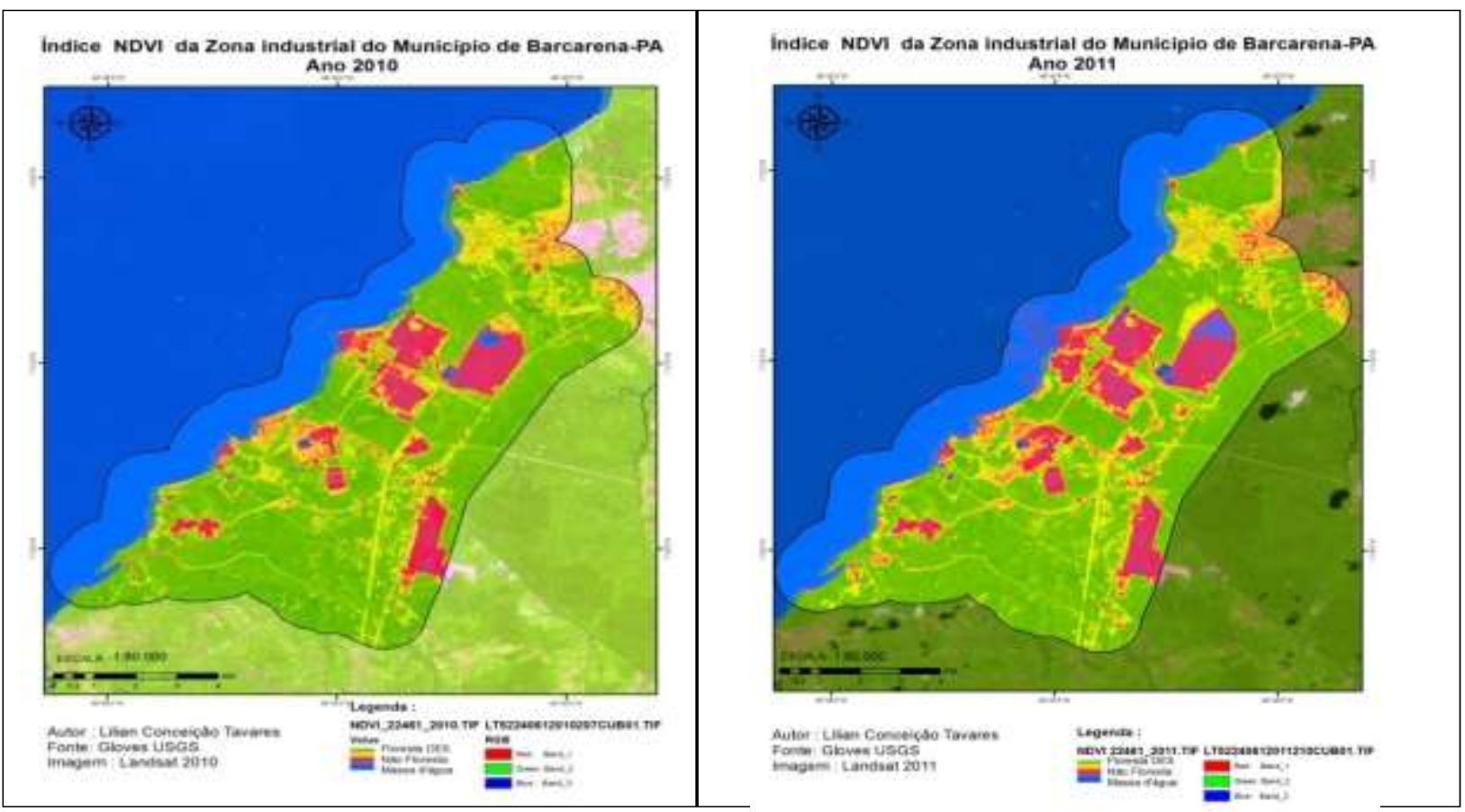

Fonte: Autores. 
Research, Society and Development, v. 10, n. 7, e23010715470, 2021

(CC BY 4.0) | ISSN 2525-3409 | DOI: http://dx.doi.org/10.33448/rsd-v10i7.15470

Figura 11 - NDVI 2012.

Figura 12 - NDVI 203.

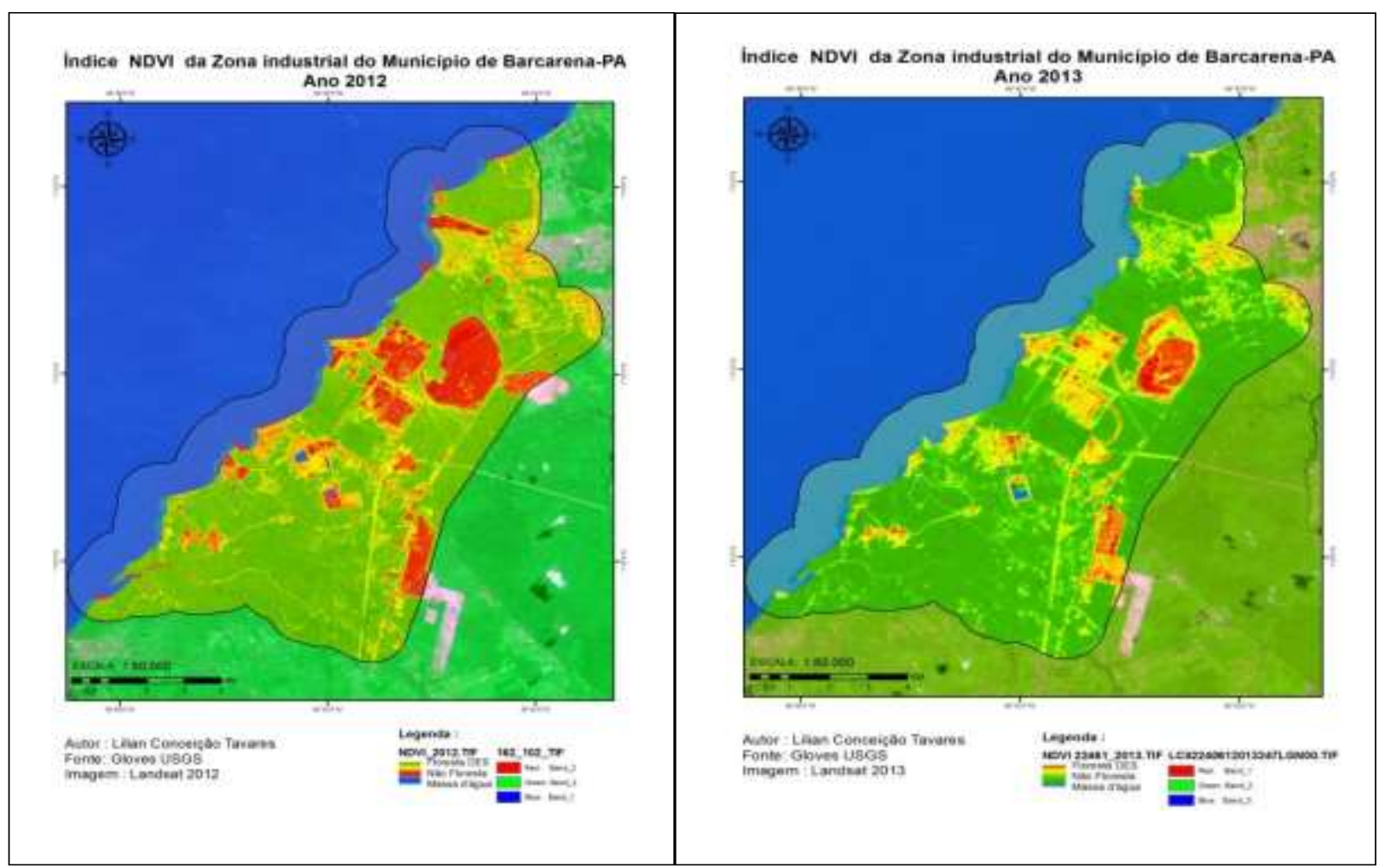

Fonte: Autores.

Figura 13 - NDVI 2014.

Figura 14 - NDVI 2015.

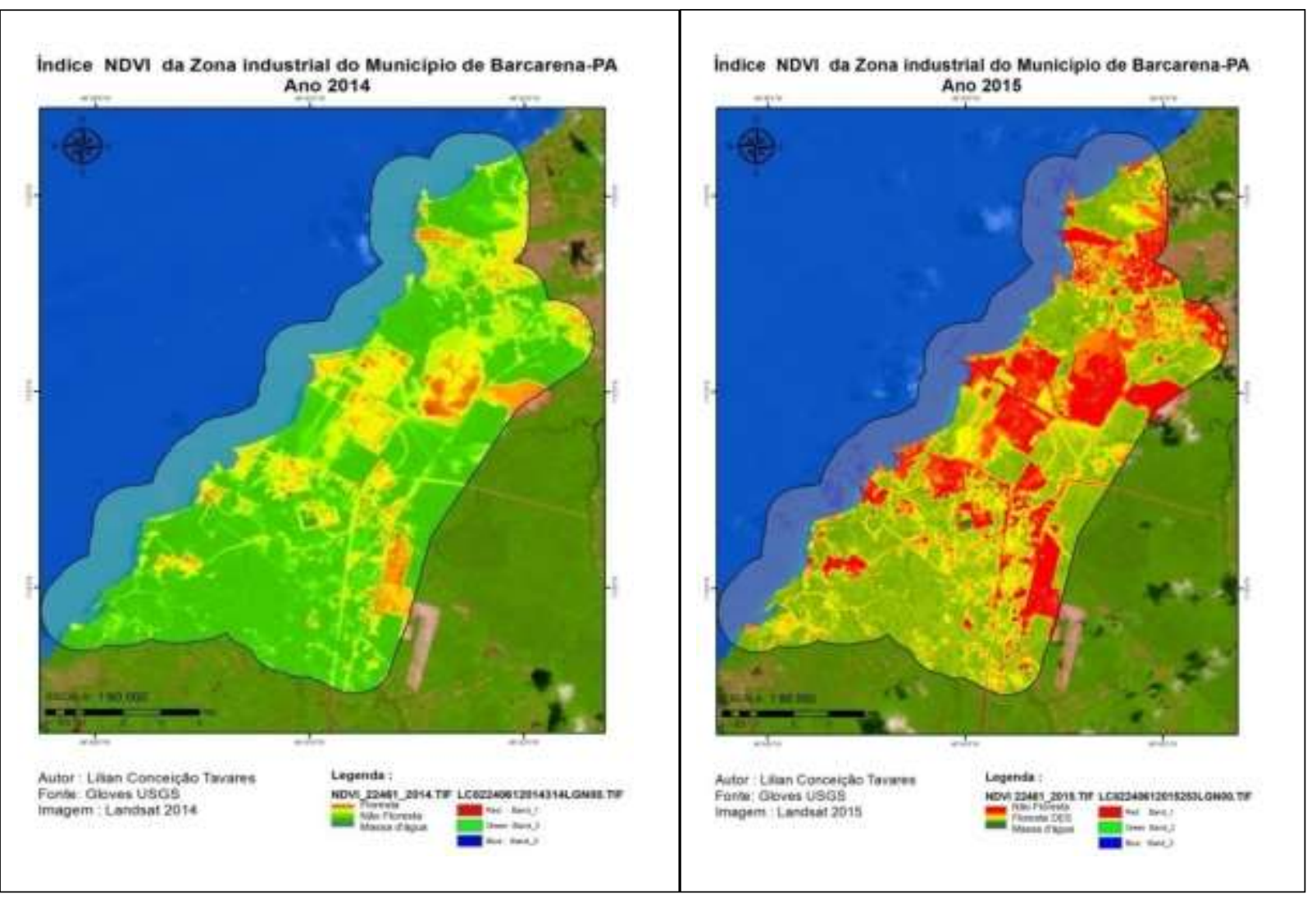

Fonte: Autores. 
Figura 15 - NDVI 2016.

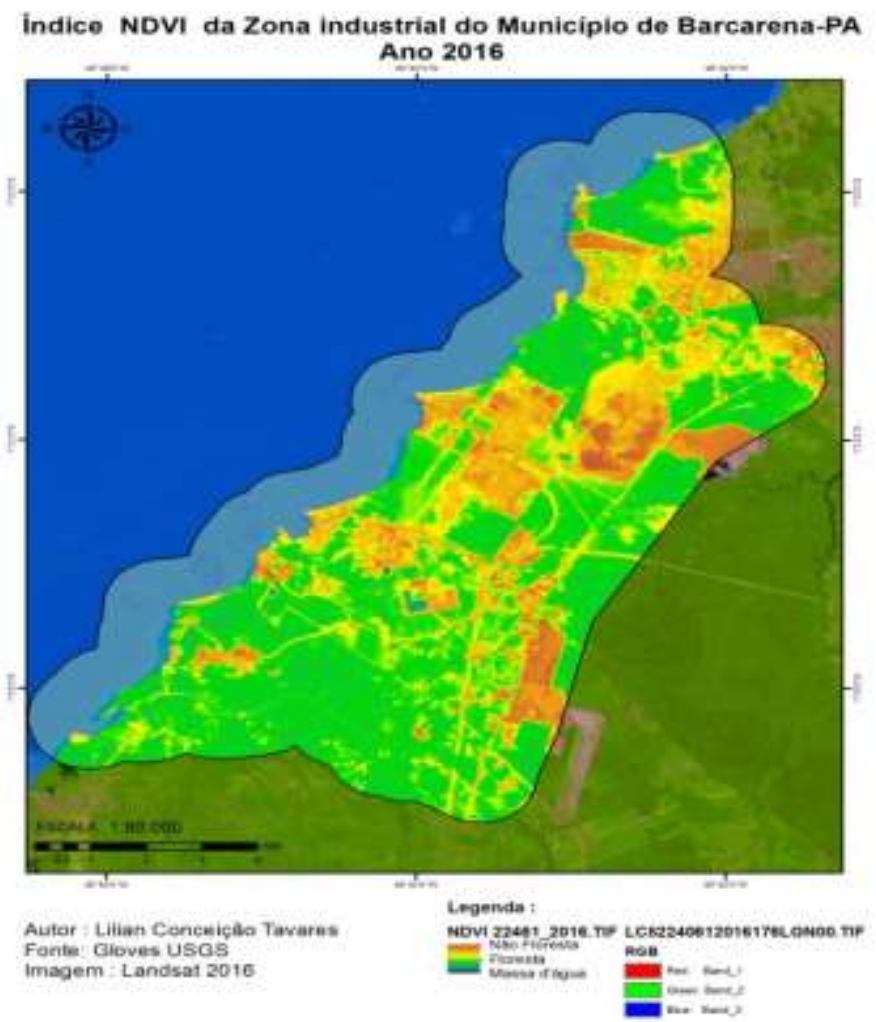

Fonte: Autores.

Assim como em muitos municípios da Amazônia, as atividades industriais em Barcarena provocaram transformações sociais e ambientais. As situações de desigualdades evoluíram no interior, com a polarização de espaços relativamente ricos e espaços pobres (Coelho et al., 2004).

Costa et al (2012) afirma que o município de Barcarena apresenta destaque no contexto local do estado do Pará, em função dos projetos industriais e atividades portuárias. A instalaçãode empresas de transformação mineral na Vila do Conde (décadas de 1980 e 1990) ocasionou o crescimento populacional que veio se dando de forma intensa, justamente por esses projetos desenvolvimentistas disporem de atrativos, os quais vêm causando diversos problemas socioambientais.

O reflexo da diminuição da Floresta DES é resultante se da, devido a desapropriaçãodos imóveis e benfeitorias de domínio particular em áreas necessárias para a implantação do projeto industrial, onde segundo (Teixeira \& Oliveira, 1995), 516 famílias foram desapropriadas e afastadas de suas atividades tradicionais, deste total apenas 14,26\% foram alocadas no único assentamento previsto no Plano Urbanístico de Barcarena (PUB) (Costa et al, 2012)

Outra consequência das áreas não floresta para a implantação de projetos foi segundo Costa et al(2012) interferir e modificar a vida das comunidades tradicionais, alterando-se o modo de relacionamento dessas pessoas com a terra e o meio ambiente e, também, as relações sociais, pois grande parte da população tradicional teve que morar em vilarejos, com poucas condições infraestruturais, sujeitando-se a trabalhar como ajudantes no processo de construção dos empreendimentos.

Segundo Costa et al (2012) o processo de industrialização interferiu e modificou a vida das comunidades tradicionais, alterando-se o modo de relacionamento dessas pessoas com a terra e o meio ambiente e, também, as relações sociais, pois grande parte da população tradicional teve que morar em vilarejos, com poucas condições infraestruturais, sujeitando-se a trabalhar como ajudantes no processo de construção dos empreendimentos. 


\section{Conclusão}

A metodologia aplicada possibilitou a comparação dos resultados da classificação das imagens da zona industrial de Barcarena através de técnicas de Processamento Digital de Imagens (PDI) e totalizando uma área de 10.422,18 ha.

Os valores obtidos por meio da álgebra de mapas e gráficos dos índices NDVI apresentaram diferenças entre os anos de 2006 a 2016 das áreas de Floresta DES e Não Floresta, onde a cobertura vegetal deve uma diminuição de área verde de 515, 084 ha, ou seja através dos gráficos e dos mapas gerados do NDVI constatou-se que houve uma perda de $12,55 \%$ da cobertura vegetal no Complexo industrial de Barcarena entre os anos de 2006 ao ano de 2016.

As comunidades que residem às proximidades das grandes empresas sofreram sérias consequências com o crescimento das empresas e com isso a diminuição da cobertura vegetal, poluição dos rios e do ar muitos moradores que viviam da extração de alimentos da floresta, saíram a procura de emprego e se somaram a uma parcela de desempregado.

Através das imagens pode-se observar que o aumento das áreas desflorestadas não é resultante apenas das instalações de empresas, e sim do grande crescimento populacional que por não ter moradia nas cidades, passam a invadir áreas florestadas ao redor da cidade. Segundo o IBGE (2017) as projeções populacionais em 2017 são de 121.190 habitantes, enquanto que em 2006, segundo IDESP (2014) a população era de 76.071 habitantes, com isso confirma a crescente área de desfloresta.

\section{Referências}

Amaral, D. D., Bastos, M. N., Silva, A. S. L., Oliveira, J., Lisboa, L. R. C., Rosário, C. S., Gomes, A., Silva, C. A. \& Aguiar, J. (2002). Inventário da Flora da região de Barcarena, Pará. Relatório Final. Belém, Ministério da Ciência e Tecnologia, Museu Paraense Emílio Goeldi.

Barbosa, L. G., \& Dorigon, L. P. (2014). Análise temporal da cobertura vegetal no município de Teresina/PI a partir da aplicação de NDVI. In XXVI Congresso Brasileiro de Cartografia V Congresso Brasileiro de Geoprocessamento XXV Exposicarta. Gramado R.S. Trabalhos Apresentados: Fotogrametria e Sensoriamento Remoto. Anais Eletrônicos: http://www.cartografia.org.br/cbc/anais_listagem_4_fotogrametria-e- sensoriamento-remoto.html.

Baret, F., \& Guyot, G. (1991). Potential and limits of vegetation indices for LAI and APAR assessment. Remote Sensing of Environment, 35:161-173.

Becard, D. S. R. (2008). O Brasil e a República Popular da China: política externa comparada e relações bilaterais (1974-2004). FUNAG.

Carmo, M. B. S.\& Costa., S. M. F. Da. (2016). Os paradoxos entre os urbanos no município de Barcarena, Pará. Revista Brasileira de Gestão Urbana (Brazilian Journalo Urban Management). 8(3), 291-305

Carmo, E. (2010). Educação e cultura em áreas de conflitos sócioterritoriais: experiências de uma comunidade nativa na amazônia oriental. In II Encontro da Sociedade Brasileira de Sociologia da Região Norte. Belém/Pa.

Coelho, A. L. N., \& Correa, W. D. S. C. (2013). Temperatura de Superfície Celsius do Sensor TIRS/Landsat-8: metodologia e aplicações. Revista Geográfica Acadêmica, 7, 31-45.

Costa, M. C., Nascimento, M. N. C. F., Maciel, M. N. M., Soares, J. A., Freitas, B. W., Filgueiras, G. C. (2012). Cadastramento e Perfil Socioeconômico das famílias da área da Companhia de Desenvolvimento Industrial do Pará, no Município de Barcarena.

Coutinho, C. H. O., Cruz, H. S.., Carneiro, F. S., Souza, C. B. G.\& Viana, J. S. 2021. Geotecnologia aplicada na avaliação de parâmetros fitossociológicos da espécie Handroanthus sp, no Estado do Pará, Brasil. Research, Society and Development, 10, e18210615437. $10.33448 / \mathrm{rsd}-\mathrm{v} 10 \mathrm{i6.15437.}$ https://rsdjournal.org/index.php/rsd/article/view/15437.

Cruz, C. L., Vasconcelos, A. C. F. De.,Oliveira, J. R. M. De. (2014). Situação de Impacto Ambiental: um estudo em uma Indústria de Extração Mineral .Qualit@s Revista Eletrônica.

Boratto, I. M., \& Gomide, R. L. (2013). Aplicação dos índices de vegetação NDVI, SAVI e IAF na caracterização da cobertura vegetativa da região Norte de Minas Gerais. In Embrapa Milho e Sorgo-Artigo em anais de congresso (ALICE). In: Simpósio Brasileiro de sensoriamento remoto, 16., 2013, Foz do Iguaçu. Anais... São José dos Campos: INPE, 2013. p. 7345-7352.

DCI, Diário de Comércio e Indústria. (2008). Vale inaugura hoje $3^{\mathrm{a}}$ expansão da Alunorte. In: Instituto Brasileiro de Mineração (Ibram), 14 ago. http://www.ibram.org.br/150/15001002.asp?ttCD_CHAVE=63476.

Elvidge, C. D., \& Lyon, R. J. P. (1985). Influence of rock-soil spectral variation on the assessment of green biomass. Remote Sensing of Environment, 17:265279.

Ferreira, P. F. M. (2011). Diagnóstico dos impactos socioambientais urbanos em Itacaré (BA). 159 p. Dissertação (mestrado) - Universidade Estadual de Campinas, Instituto de Geociências, Campinas, SP. http://www.repositorio.unicamp.br/handle/REPOSIP/286904.

Giongo, P. R. (2008). Estimativa do balanço de radiação com técnicas de sensoriamento remoto e dados de superfície. 92f. Dissertação (Mestrado em Engenharia Agrícola) - Universidade Federal Rural de Pernambuco, Recife. Silva, A. C. D., Vidal, M., \& Pereira, M. 
Hosokawa, E. K., Costa, D. C., \& Rutkowski, E. W. (2010). Geotecnologias livres aplicadas no planejamento territorial. Revista Nacional de Gerenciamento de Cidades, 02, 77-92 IBGE. Censo Demográfico. http://www.censo2010.ibge.gov.br.

IBGE. Instituto Brasileiro de Geogradia e Estatística. (2015). Cidades 2015. http://cidades.ibge.gov.br/xtras/perfil.php?codmun=150130.

IDESP- Instituto de desenvolvimento econômico, social e ambiental do Pará. (2014). http://www.fapespa.pa.gov.br/upload/Arquiv o/anexo/385.pdf?id=1536683299.

INPE- Instituto nacional de pesquisas especiais. (2016). http://www.cbers.inpe.br/sobre_satelite/historico.php.

IBAMA- Instituto brasileiro do meio ambiente e dos recursos naturais renováveis - (2016). http://www.ibama.gov.br/phocadownload/b arragemdefundao/notastecnicas/2016-02-nota_tecnica_001-2016.pdf.

Jensen, J. R. (2009). Sensoriamento Remoto do Ambiente: uma perspectiva em recursos terrestres. (2a ed.), São José dos Campos: Parêntese, 604 p

Junior, W. D. S., \& Ribeiro, G. P. (2012). Qualidade dos dados geográficos disponibilizados em ambiente de Sistema De Informação Geográfica na Internet. IV Simpósio brasileiro de ciências geodésicas e tecnologias da geoinformação, Anais. Recife, p. 06-09.

Lima, G. C., Silva, M. L. N., Curi, N., Silva, M. A., Oliveira, A. H., Avanzi, J. C., Ummus, M. E. (2013). Avaliação da cobertura vegetal pelo índice de vegetação por diferença normalizada (IVDN). Ambi-Agua, Taubaté, 8, 204-214. http://dx.doi.org/10.4136/ambi-agua.959.

Lima, M. De O,, Vieira, V. De C.B. (2009). Uso de Geotecnologias para análise da cobertura vegetal urbana.Natal. p731-738.30 Abril.

Lobato, R., Menezes, J., Lima, L. A., Sapienza, J. A. (2011). Índice de vegetação por diferença normalizada para análise da redução da mata atlântica na região costeira do distrito de Tamoios-Cabo Frio/RJ. Caderno de Estudos Geoambientais-CADEGEO http://www.cadegeo.uff.br/index.php/cadegeo/article/view/2/2.

Medeiros, B. M., Lisboa,F.D.S., Duarte, I. G., Silvino. G.S. Da. (2016). Análise temporal comparativa do comportamento da vegetação em área semiárida na região da bacia hidrográfica do Rio Farinhas, Patos - PB. In: Congresso internacional da diversidade do semiárido, 1., Campina Grande. Anais eletrônicos. http://www.editorarealize.com.br/revistas/conidis/anais.php.

Meneses, P. R., Almeida, T. (Org.). (2012). Introdução ao processamento de imagens de sensoriamento remoto. Brasília: Universidade de Brasilia. 276 p. http://www.cnpq.br/documents/10157/56b578c4-0fd5-4b9f-b82a-e9693e4f69d8.

Moreira, M. A. (2012). Fundamentos de Sensoriamento Remoto. INPE.

Ponzoni, F. J., Shimabukuro, Y. E., Kuplich, T. M. (2012). Sensoriamento Remoto da Vegetação. 2. ed. São Paulo: Oficina de Textos,. v. 1, 176p.

Ribeiro, E. S., Raad, S. M., Nascimento, R. S. C., Reis, N. S., Faro, B. L. S. O., Carneiro, F. S.\& Santos, J. C. 2020. Análise da distribuição espacial da cobertura vegetal no município de Santa Barbara/PA. Natural Resources, 10, 8-14. https://doi.org/10.6008/CBPC2237-9290.2020.003.0002.

Ribeiro, E. S., Faro, B. L. S.O., Nascimento, R. S. C., Carneiro, F. S., Amaral, A. P. M., Bezerra, M. G. S., Amorim, M. B.\& Garcia, T. S. 2021. Avaliação multitemporal da cobertura vegetal da reserva biológica de Tapirapé, Pará. Research, Society and Development, 10, e50910414345, 2021. DOI: 10.33448/rsdv10i4.14345.

Rosário, R. R., Barbosa, M. T., Carneiro, F. S.\& Costa, M. S. S. 2021. Uso e ocupação do solo do município de novo progresso no Estado do Pará-Brasil. Research, Society And Development, 10, e51210112060-e51210112060. https://doi.org/10.33448/rsd-v10i1.12060.

Santos, J. C., Barros, J. W. C., Marinho, F. G. G., Sakuma, F. Y. S., Novais, T. N. O., Nascimento, J. L. P.\& Carneiro, F. S. 2020. Caracterização do uso e cobertura do solo do município de Concórdia do Pará utilizando geotecnologias. Natural Resources, 10, 33-37. https://doi.org/10.6008/CBPC22379290.2020.002.0004.

Salomão, R. De P., Vieira, I. C. G., Brienza Junior, S., Amaral, D. D. Do, Santana, A. C. de (2012). Sistema capoeira classe: uma proposta de sistema de classificação de estágios sucessionais de florestas secundárias para o estado do Pará. Embrapa Amazônia Oriental-Artigo em periódico indexado (ALICE). https://www.embrapa.br/busca-de-publicacoes/-/publicacao/950752/sistema-capoeira-classe-uma-proposta-de-sistema-de-classificacao-de-estagiossucessionais-de-florestas-secundarias-para-o-estado-do-para

Souza, A. P. S. L., Lobato, R. C. (2005). Musgos (Bryophyta) na Ilha Trambioca, Barcarena, PA, Brasil. Acta Botanica Brasilica. 19, 487-492. ISSN 01023306. https://doi.org/10.1590/S0102-33062005000300008.

Souza, C. B. G., Carneiro, F. S., Rodrigues, H. C. T., Ribeiro, E. G. P., Amaral, A. P. M., Silva, J. S. L. P., Araujo, S. C. A.\& Castro, C. V. B. 2021. Análise espaço-temporal de Área de Proteção Permanente para a gestão ambiental municipal em Parauapebas no estado do Pará-Brasil. Research, Society and Development, 10, e24110615491. DOI: 10.33448/rsd-v10i6.15491.

Trindade Jr., S. C. \& Chagas, C. A. N. (2002). A company Town do alumínio: Concepção e práticas espaciais. In: Trindade Jr., S. C. \& Rocha, G. M. Cidade e empresa na Amazônia: gestão do território e desenvolvimento local. Belém: Pakatatu, 195-235.

USGS. 2014. Vegetation Indices 16-Day L3 Global 250 m. MOD13Q1. https://lpdaac.usgs.gov/ dataset_discovery/modis/modis_products_table/mod13q1.

Xavier Da Silva, J. (2007). Geoprocessamento em estudos ambientais: Uma perspectiva sistêmica (Cap. 1). Meirelles, M. S. P., Camara G., Almeida M. Geomática: modelos e aplicações ambientais. Brasília, DF: EMBRAPA Informação tecnológica. 593 p. 21 -53.

Zaidan, R. T., Silva, J. X. (2004). Geoprocessamento aplicado ao zoneamento de áreas com necessidade de proteção: o caso do Parque Estadual do Ibitipoca - MG. In: Jorge Xavier da Silva, Ricardo Tavares Zaidan. (Org.). Geoprocessamento e Análise Ambiental: Aplicações. Bertrand Brasil, 10, 31-66. 